Yol.2 2Nn. I لanuari 2019

ISSN 2614-2775

e-ISSN 2621-8143

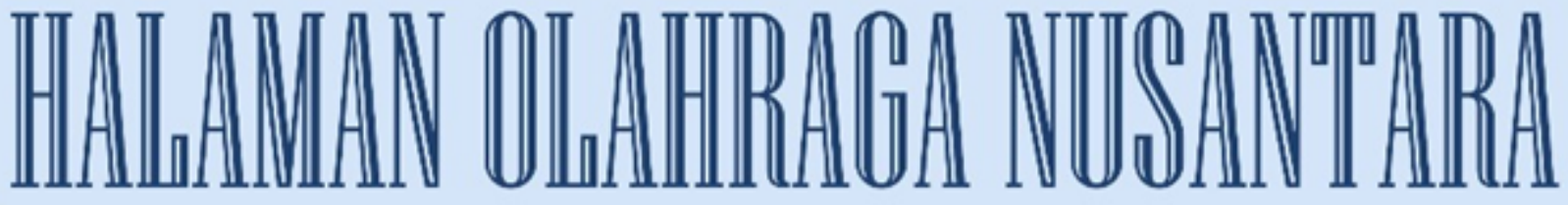

Surnal @lmu Xeolahragaan

Diterbitkan Oleh:

Program Studi Pendidikan Olahraga

Fakultas Keguruan dan Ilmu Pendidikan

Universitas PGRI Palembang

Jurnal

Volume Nomor Halaman Palembang ISSN/e-ISSN

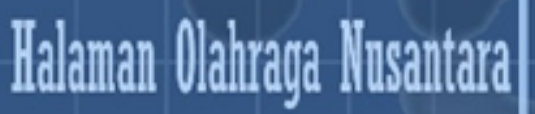

\begin{tabular}{l|l|l|l}
2 & 1 & $1-96$ & 2019
\end{tabular}




\section{Halaman Olahraga Nusantara}

Jurnal Ilmu Keolahragaan

Volume 2, Nomor 1, Januari 2019

Pelindung/Penasehat

Dr. H. Bukman Lian, M. M., M. Si.

Penanggung Jawab

Dr. Dessy Wardiah, M. Pd.

Ketua Dewan Redaksi

Farizal Imansyah, M. Pd.

Wakil Ketua Dewan Redaksi

Ilham Arvan Junaidi, M. Pd.

Sekretaris

Bayu Iswana, M. Pd.

Penyunting Pelaksana

Rafel Orlando, M. Pd.

Ardo Okilanda, M. Pd.

Daryono, M. Pd.

\section{Mitra Bestari}

Prof. Dr. A. Sofyan Hanif, M. Pd (Universitas Negeri Jakarta)

Dr. Sukirno (Universitas Sriwijaya)

Dr. Ronni Yenes, M. Pd (Universitas Negeri Padang)

Dr. Benny, M. Pd. (Universitas Negeri Makasar)

Dr. Putri Cicilia Kristina, M. Pd (Universitas PGRI Palembang)

\section{Tata Usaha}

M. Taheri Akbar, M. Pd.

Widya Handayani, S. Pd., M. Si.

Setting:

Dede Dwiansyah Putra, M. Pd.

Alamat Redaksi:

Prodi Pendidkan Olahraga Fakultas Keguruan Ilmu dan Pendidikan Universitas PGRI Palembang

Jl. Jendral A. Yani Lorong Gotong Royong 9/10 Ulu Palembang

Telp. 0711-510043, Fax. 0711-514782

e-mail jurnal: jurnalhonupgripalembang@gmail.com

e-mail : ardo.oku@univpgri-palembang.ac.id

website: univpgri-palembang.ac.id 
Halaman Olahraga Nusantara (Jurnal Ilmu Keolahragaan)

P-ISSN 2614-2775

Volume 2, No. 1, Januari 2019

E-ISSN 2621-8143

\section{DAFTAR ISI}

Hasil Penelitian

Halaman

Pengaruh Metode Rangkaian Bermain Terhadap Keterampilan Dasar Olahraga Panahan Siswa Ektrakulikuler Sit (Sekolah Islam Terpadu) Auladi Palembang

- Arisman

Penerapan Metode Bermain Dalam Meningkatkan Hasil Belajar Guling Depan (Forward Roll)

- Ruslan, M. Samsul Huda

Survei Tingkat Kesegaran Jasmani pada Peserta Ekstrakulikuler Sepakbola Di Sma Negeri 2 Oku

- Daryono

Kontribusi Daya Ledak Tungkai dan Keseimbangan Terhadap Kemampuan Lompat Jauh Murid Sd Negeri 139 Sinjai

- Adam Mappaompo

Survei Tingkat Kebugaran Jasmani Mahasiswa Pendidikan Olahraga Angkatan 2017 Stkip Pgri Bangkalan

- Heni Yuli Handayani .

Profil Delayed Onset Muscle Soreness (Doms) pada Mahasiswa Fik Unp Setelah Latihan Fisik

- Heru Syarli Lesmana

Perbedaan Pengaruh Latihan Menggunakan Karet dengan Menggunakan Dumbbell $1 \mathrm{Kg}$ Terhadap Kecepatan Pukulan Oi Tsuki

Chudan pada Atlet Karate Putra Perguruan Wadokai Dojo Sma Negeri 11 Medan Tahun 2017

- Pangondian Hotliber Purba $60-71$

Tinjauan Kondisi Fisik Atlet Sepakbola Kabupaten Kerinci Dalam

Rangka Persiapan Mengikuti Porprov Xxii Bungo Tebo 2018

- Palmizal, Wawan Junresti Daya, dan Sri Murniati

Aktivitas Jasmani dan Persepsi Gerak Anak Usia Dini

- Dian Pujianto 
Peningkatan Keterampilan Bermain Bolabasket Mahasiswa Melalui Latihan Aktifitas Maze Perkuliahan Permainan Bolabasket

- Ilham Arvan Junaidi dan Rury Rizhardy $88-96$ 


\title{
AKTIVITAS JASMANI DAN PERSEPSI GERAK ANAK USIA DINI
}

\author{
Oleh: Dian Pujianto \\ (Dosen Universitas Bengkulu)
}

\begin{abstract}
Abstrak
Penelitian ini bertujuan untuk mengetahui pengaruh aktivitas jasmani terhadap kemampuan persepsi gerak anak usia dini. Populasi penelitian ini adalah 16 siswa TK kelas B, TK ABA Sermo, Sermo, Sumberarum, Moyudan, Sleman, Yogyakarta. Teknik pengambilan sampel menggunakan total sampel karena sampel penelitian menggunakan seluruh populasi yang ada. Studi eksperimental menggunakan desain penelitian Pretest-Posttest Group Design dengan. Analisis statistik yang digunakan adalah Uji Anava satu jalur. Hasil penelitian menunjukkan FO sebesar 8,41 dan Ftabel sebesar 4,60. Berdasarkan hasil perhitungan dapat ditarik kesimpulan bahwa aktivitas jasmani secara nyata memberikan pengaruh terhadap kemampuan persepsi gerak anak usia dini.
\end{abstract}

Kata Kunci: Aktivitas Jasmani, Persepsi Gerak, Anak Usia Dini

\section{PHYSICAL ACTIVITY AND CHILDREN MOTOR PERCEPTUAL}

\begin{abstract}
This study aims to find out the effect of physical activities on the ability of the perceptual-motor of early childhood. The population of this study is 16 students of class B grade, Kindergarten ABA Sermo, Sermo, Sumberarum, Moyudan, Sleman, Yogyakarta. The sampling technique uses a total sample because the research sample uses the entire population. Experimental research using pretest-posttest group design. Statistical analysis is a one-way Anava Test. The results showed $F_{O}$ of 8.41 and $F_{\text {table }}$ of 4.60 . Based on the calculation results can be concluded the existence of physical activity significantly affect the ability of perceptual-motor in early childhood.
\end{abstract}

Keywords: Physical Activity, Motor Perceptual, Children

\section{A. PENDAHULUAN}

Perkembangan jaman telah mulai merubah budaya masyarakat. Masyarakat yang dulunya aktif melakukan aktivitas jasmani mulai bergeser menjadi malas untuk beraktivitas jasmani. Budaya aktif bergerak menjadi malas bergerak. Perubahan budaya ini tidak hanya berubah pada orang dewasa, akan tetapi terjadi pada generasi muda atau anak. Anak memiliki kebutuhan untuk bergerak sebagai wahana perkembangan diri anak. Anak yang memiliki waktu 
gerak yang banyak memiliki kondisi fisik yang lebih baik daripada anak yang malas beraktivitas fisik (Ellis et al., 2017).

Pertumbuhan dan perkembangan anak akan menjadi lebih baik jika anak diberikan kesempatan untuk beraktivitas jasmani di luar ruangan, berinteraksi dengan lingkungan, bersosialisasi dengan teman-teman sebayanya (Bento \& Dias, 2017). Berdasarkan uraian di atas jelas keuntungan aktivitas jasmani terhadap pertumbuhan dan perkembangan anak. Akan tetapi pada kenyataannya orangtua sekarang cenderung over protektif terhadap anak. Anak selalu dibatasi ketika akan bermain dan cenderung dilarang untuk beraktivitas fisik. Anak lebih banyak duduk dan melihat gadget yang cenderung menambah malas anak untuk beraktivitas. Rasa malas beraktivitas anak menyebabkan kontrol emosi anak kurang, hal ini dapat terlihat perilaku anak saat ini yang mudah meluapkan emosinya dengan berteriak, membanting benda, berkata kasar pada orangtua. Pada saat mereka menginjak dewasa mereka telah berani melakukan tindak kejahatan di luar batas apa yang seharusnya dilakukan oleh para remaja, seperti merampok dan membunuh.

Berdasarkan uraian di atas jelas bahwa kebutuhan anak untuk bermain penting sebagai salah satu media untuk mengembangkan kognitif, afektif, dan psikomotor mereka. Kajian ini akan memberikan gambaran tentang pentingnya aktivitas jasmani terhadap perkembangan persepsi gerak pada anak. (Taraw N.B, 1981) anak mempunyai keperluan untuk;

1. Menyalurkan aktivitas dengan penuh semangat, karena ini adalah kebutuhan biologis dari si anak.

2. Meningkatkan penyempurnaan pola saraf otot untuk koordinasi.

3. Penyediaan kesempatan untuk beraktivitas, antara;

a. Pelaksanaan ketrampilan dan teknik yang menggunakan system otot secara total.

b. Aktivitas dengan irama, meliputi permainan dengan musik.

c. Ketrampilan ketangkasan dan peralatan permainan.

d. Permaianan kejar-kejaran dan berlari yang memerlukan kecepatan. 
e. Permainan tim dengan organisasi yang simple tetapi setiap anak bisa bermain dengan penuh semangat.

4. Aktivitas bersama antara anak putra dan anak putri secara berkelompok.

5. Meningkatkan mekanika tubuh untuk memperoleh pembesaran otot.

Kebutuhan anak yang disebutkan di atas adalah sedikit dari banyak kebutuhan atau kepentingan yang harus diberikan orangtua pada anak-anaknya di usia dini. Kebutuhan anak memang sangatlah komplek, dari kompleknya kebutuhan anak ini maka wajib bagi orangtua untuk mampu mengaturnya. Dalam mengatur kebutuhan anak orangtua harus mengetahui apa keinginan anak dan tahap perkembangan anak tersebut, dalam hal ini anak pada usia dini tentu lebih memerlukan untuk melakukan eksplorasi dengan alam sekitarnya melalui bermain atau gerak, karena pada masa ini menurut (E.B., 1978) adalah masa anak-anak mulai mempelajari kemampuan motorik. Hal ini disebabkan oleh beberapa alasan, antara lain:

1. Pada saat ini tubuh anak mulai besar sehingga mudah menerima pembelajaran tentang aktivitas jasmani.

2. Anak belum banyak mempunyai ketrampilan yang akan berbenturan dengan ketrampilan yang baru dipelajarinya atau dengan kata lain ketrampilan anak pada masa ini masih sangat sedikit.

3. Anak pada usia ini akan lebih berani apabila dibandingkan dengan anak yang lebih besar usianya, anak pada usia ini lebih berani mencoba hal yang baru, hal ini menimbulkan motivasi yang penting untuk belajar gerak.

4. Jika para remaja dan orang dewasa bosan dengan pengulangan maka anakanak sebaliknya yaitu menyukainya.

Anak-anak usia dini memiliki tanggung jawab lebih kecil sehingga mereka memiliki waktu yang lebih banyak untuk belajar menguasai keterampilan daripada apa yang dimiliki oleh remaja.

Hal di atas merupakan beberapa alasan yang telah dikemukakan oleh para ahli mengapa anak usia dini lebih cenderung harus mempelajari kemampuan motorik atau geraknya. Sehingga dapat disimpulkan bahwa anak pada usia dini 
adalah saat yang tepat untuk mengembangkan kemampuan motorik atau gerak dari si anak. Pada kenyataannya di Dusun Sermo khususnya perhatian tentang gerak pada anak mulai berkurang. Anak usia dini lebih cenderung berdiam diri di rumah dengan gadget mereka. Jika ini berlangsung terus menerus akan berakibat lemahnya kondisi fisik dan kemampuan gerak mereka. Pada saat dewasa mereka akan menjadi manusia yang lemah.

\section{B. METODE PENELITIAN DAN PEMBAHASAN}

Penelitian ini menggunakan metode ekperimen dengan desain pre test posttest desain. Populasi dari penelitian ini adalah siswa TK B TK ABA Sermo. Teknik pengambilan sampel menggunakan teknik total sampel, karena populasi kurang dari 100. Sampel penelitian adalah anak TK B, TK ABA Sermo, yang berusia 5 tahun. Jumlah sampel adalah seluruh anak yang ada di TK B, berjumlah 8 anak. Perlakuan dilakukan 16 kali pertemuan, dengan pertemuan 3 kali dalam 1 minggu. Perlakuan yang diberikan adalah latihan gerak berdasarkan latihan gerak anak usia dini yang dikembangkan oleh Aussie Sport Australia.

Teknik pengumpulan data menggunakan tes, tes persepsi gerak. Tes ini terdiri dari beberapa tugas gerak, antara lain; 1) Keseimbangan, 2) Koordinasi tangan dan mata 3) Daya gerak 4) Pemahaman ruang, dan 5) Irama, kemampuan mendengar. Butir-butir pengamatan terhadap tugas gerak yang diberikan pada siswa ini diberikan skor, sehingga diperoleh skor maksimal 27 dan skor minimal 0. Analisis data menggunakan Anava satu jalur, dan sebelum uji Anava satu jalur dilaksanakan dilakukan uji prasyarat uji normalitas dan homogenitas.

Berdasarkan data yang tersaji di atas bisa diketahui, 50\% (4 anak) berada di bawah rata-rata. 50\% (4 anak) berada dalam rata-rata, 37.5\% (3 anak) berada dalam rata-rata , 62.5\% berada di atas rata-rata kemampuan persepsi motorik anak. Berdasarkan data di atas bahwa harga Lillifors hitung lebih kecil dari harga Lillifors table, sehingga dapat disimpulkan bahwa data berasal dari populasi yang normal. Data berdistribusi normal, selanjutnya akan dilakukan uji homogenitas varians dari data, Berikut ini rangkuman data hasil uji normalitas data yang telah dilakukan; 
Tabel 5. Rangkuman Uji Homogenitas Varians

\begin{tabular}{ccccc}
\hline Data & ${\text { Varians }\left(s^{2}\right)}$ & $\begin{array}{c}\text { F Hitung } \\
\text { Varians terbesar/Varians } \\
\text { terkecil }\end{array}$ & F Tabel & Kesimpulan \\
& & & & \\
\hline \hline Pre Test & 5.125 & 1.216 & 3.79 & Homogen \\
Post Test & 4.214 & & & \\
\hline
\end{tabular}

Berdasarkan hasil perhitungan seperti yang terlampir dalam tabel di atas, terlihat harga varians terbesar 5,125 dari data tes awal, harga varians terkecil 4,214 dari data tes akhir. Dari hasil pembagian varians terbesar dibagi varians terkecil diperoleh 1,216, harga ini dibandingkan dengan harga $\mathrm{F}$ dengan taraf signifikasi $\square 0,05$ dan dk pembilang (8-1), dk penyebut (8-1) diperoleh harga 3.79. Jadi $F$ 1.216 lebih kecil dari $F$ 3,79, sehingga berdasarkan hal ini bisa ditarik kesimpulan bahwa populasi mempunyai varians yang sama besar atau homogen, data mempunyai distribusi yang homogen atau sama.

Dari hasil perhitungan dengan analisis varians satu jalur yang telah dicatat bahwa harga $\mathrm{F}$ hitung sebesar 8.42. Kemudian dibandingkan dengan $\mathrm{F}$ tabel, yang terdapat pada table yang terdapat pada kolom keenam terdapat harga $\mathrm{F}$ tabel sebesar 4.60, dari harga ini dapat dilihat bahwa harga $\mathrm{F}$ hitung lebih besar daripada harga F tabel. Sehingga Hi diterima dan Ho ditolak. Dan dapat ditarik sebuah kesimpulan bahwa aktivitas jasmani telah memberikan pengaruh atau efek terhadap meningkatnya persepsi gerak anak TK B secara signifikan.

Data kemampuan persepsi gerak anak pada awalnya tergolong rendah, hal ini diketahui dari hasil tes awal yang telah dilakukan. Kemudian anak masuk dalam program aktivitas jasmani berdasarkan kurikulum aktivitas yang dikembangkan oleh Aussie Sport. Setelah 16 kali pertemuan kemudian dilakukan tes akhir, dan hasil data tes akhir menunjukkan adanya peningkatan rata-rata data. Selanjutnya untuk melihat peningkatan rata-rata data signifikan atau tidak, maka dilanjutkan dengan uji statistik, dengan uji Anava Satu Jalur. Hasil dari pengujian menunjukkan bahwa ada perbedaan yang signifikan mean data awal persepsi 
motorik anak TK B apabila dibandingkan dengan mean data akhirnya, sebagai pengaruh dari perlakuan aktivitas jasmani. Kesimpulannya terdapat perbedaan persepsi motorik setelah anak melakukan aktivitas jasmani. Dari hasil analisis ini juga menunjukkan adanya kesesuaian dengan teori, yaitu anak yang diberikan suatu perlakuan dengan waktu, intensitas, beban yang sesuai akan meningkat keterampilan dan kemampuannya. Dengan menggunakan aktivitas jasmani telah terbukti mampu meningkatkan persepsi motorik anak secara signifikan.

Aktivitas jasmani secara nyata telah memberikan pengaruh positif terhadap perkembangan dan pertumbuhan dari anak. (Ellis et al., 2017) menyatakan bahwa aktivitas jasmani pada waktu luang secara nyata memberikan efek positif terhadap perkembangan anak. Berdasarkan hasil penelitian menyatakan bahwa aktivitas jasmani telah memberikan media bagi anak untuk mengembangkan kemampuan menolong diri sendiri, mengontrol emosi dan bersosialisasi dengan lingkungan masyarakat sekitar (Vazou, Mantis, Luze, \& Krogh, 2017). Dua hasil penelitian di atas membuktikan peran aktivitas jasmani pada anak.

Aktivitas jasmani selain berperan untuk memaksimalkan pertumbuhan anak, juga berperan penting dalam perkembangan anak. Perkembangan anak secara sosial, emosi, dan cara berpikir mereka dalam memecahkan persoalan yang dihadapi oleh anak. Pengetahuan tentang peran aktivitas jasmani pada anak yang kurang, seringkali membuat orangtua selalu over protektif terhadap apa yang dilakukan oleh anaknya. Sehingga yang terjadi adalah anak menjadi tidak mampu berekspresi dengan aktivitas jasmani yang berakibat pada terganggunya pola pertumbuhan dan perkembangan anak. Ketika anak kurang dalam mengekspresikan diri melalui aktivitas jasmani maka kesehatan mental anak akan terganggu.

Ada korelasi antara kesehatan mental dengan pola dan waktu aktivitas jasmani pada anak (Ohrnberger, Fichera, \& Sutton, 2017). Anak-anak yang cenderung memiliki waktu beraktivitas jasmani lebih sedikit ternyata lebih beresiko memiliki masalah kesehatan mental. Selain kesehatan mental,kesehatan secara umum juga dipengaruhi oleh jumlah aktivitas fisik anak. Ada korelasi antara kesehatan anak dan aktivitas jasmani, serta ada korelasi antara aktivitas 
jasmani dan prestasi akademik pada anak (Shi et al., 2014). Hasil penelitian ini menyatakan bahwa aktivitas jasmani memberikan derajat kesehatan yang baik dan aktivitas jasmani memiliki korelasi yang positif terhadap prestasi akademik dari anak di sekolah.

Aktiftas jasmani yang teratur dan terukur akan memberikan kemampuan kognitif anak menjadi baik dan akan berimbas pada prestasi akademik dari anak (Tandon et al., 2016). Kemampuan kognitif anak berkembang ketika anak berkatifitas jasmani dengan teman-temannya, ketika bermain mereka akan belajar memecahkan permasalahannya secara mandiri. Pada tahap ini otak anak sedang berkembang dan akan berkembang secara optimal ketika anak beraktivitas jasmani dan berpikir memecahkan masalah yang ada pada dunia anak.

Kemampuan kognitif anak berkaitan dengan kemampuan anak dalam mempersepsikan kondisi lingkungan sekitar. Persepsi adalah bagiamana mengambarkan situasi sekitar. Tahap perkembangan persepsi pada anak terjadi antara usia 4 sampai 6 tahun (David L. Gallahue, 1998). Persepsi yang dimaksud adalah persepsi gerak, kemampuan anak dalam menggambarkan situasi lingkungan dengan merespon melalui gerak. Tahap ini penting dalam perkembangan otak anak, karena mulai mampu berpikir dan memecahkan masalah. Persepsi gerak dapat dikembangkan secara optimal melalui aktivitas jasmani.

Hasil dari penelitian ini membuktikan bahwa aktivitas jasmani secara signifikan memberikan pengaruh terhadap peningkatan kemampuan persepsi gerak pada anak. Aktivitas jasmani memberikan pengaruh terhadap kemampuan persepsi gerak pada anak (Elena, Georgeta, Cecila, \& Lupu, 2014). Melalui aktivitas jasmani anak-anak dapat mengembangkan segala potensi yang dimilikinya. Anak dapat tumbuh dan berkembang sesuai dengan tahapan pertumbuhan dan perkembangannya jika aktivitas jasmaninya sesuai dengan usia anak. Dalam memberikan aktivitas jasmani orangtua, guru, atau pelatih harus mengerti dan mengetahui tahapan pertumbuhan dan perkembangan anak.

Perkembangan persepsi gerak yang baik akan memberikan anak kemampuan untuk memecahkan masalah dan pemahaman terhadap lingkungan 
dengan baik. Dengan demikian anak akan mampu untuk mandiri memecahkan masalah dan mampu bersosialisasi dengan lingkungan sekitar. Ketika tahap persepsi gerak dapat berkembang sesuai dengan tahapannya, maka ini akan menjadi dasar untuk tahap keterampilan gerak berikutnya. Anak yang memiliki dasar yang baik dalam perkembangannya akan lebih siap untuk menghadapi lingkungannya pada saat anak dewasa. Melalui aktivitas jasmani yang teratur dan terukur anak akan mempu mengembangkan seluruh potensi yang dimilikinya, anak akan mengalami proses pertumbuhan dan perkembangan sesuai dengan tahapannya.

\section{KESIMPULAN}

Aktivitas jasmani secara nyata memberikan pengaruh yang nyata terhadap kemampuan persepsi gerak pada anak. Pernyataan ini dibuktikan melalui hasil penelitian yang telah dilakukan. Dianjurkan bagi orangtua untuk memberikan aktivitas jasmani yang cukup bagi anak-anaknya.

\section{DAFTAR PUSTAKA}

Bento, G., \& Dias, G. 2017. Development. Porto Biomedical Journal, 2(5), 157160. https://doi.org/10.1016/j.pbj.2017.03.003

David L. Gallahue, J. C. O. 1998. Understanding Motor Development infant, Children, Adolescents, Adults (Fourth). Singapore: McGrawHill.

E.B., H. 1978. Perkembangan Anak. Jakarta: Erlangga.

Elena, S., Georgeta, N., Cecila, G., \& Lupu, E. 2014. Perceptual-motor development of children in elementary school. Procedia - Social and Behavioral Sciences, 114, 632-636. https://doi.org/10.1016/j.sbspro.2013.12.759.

Ellis, Y. G., Cliff, D. P., Janssen, X., Jones, R. A., Reilly, J. J., \& Okely, A. D. 2017. Sedentary time, physical activity and compliance with IOM recommendations in young children at childcare. Preventive Medicine Reports, 7, 221-226. https://doi.org/10.1016/j.pmedr.2016.12.009.

Ohrnberger, J., Fichera, E., \& Sutton, M. 2017. Social Science \& Medicine The relationship between physical and mental health: A mediation analysis. 
Social Science \& Medicine, 195(October), 42-49. https://doi.org/10.1016/j.socscimed.2017.11.008.

Shi, X., Tubb, L., Chen, S., Fulda, K. G., Franks, S., Reeves, R., \& Lister, G. 2014. ScienceDirect Associations of health disparities and physical activity with children' $s$ health and academic problems. Journal of Exercise Science \& Fitness, 12(1), 7-14. https://doi.org/10.1016/j.jesf.2013.12.003.

Sudjana. 2001. Metoda Statistika. Bandung: Tarsito.

Tandon, P. S., Tovar, A., Jayasuriya, A. T., Welker, E., Schober, D. J., Copeland, K., ... Ward, D. S. 2016. The relationship between physical activity and diet and young children a€TM s cognitive development: A systematic review. PMEDR, 3 , 379-390. https://doi.org/10.1016/j.pmedr.2016.04.003.

Taraw N.B, L. S. W. (1981). Aktivities and Resources for Guiding Young Children Learning. New York: McGrawHill.

Vazou, S., Mantis, C., Luze, G., \& Krogh, J. S. 2017. Self-perceptions and social - emotional classroom engagement following structured physical activity among preschoolers: A feasibility study. Journal of Sport and Health Science, 6(2), 241-247. https://doi.org/10.1016/j.jshs.2016.01.006. 


\section{GAYA SELINGKUNG}

1. Jurnal Halaman Olahraga Nusantara menerbitkan karya ilmiah dan hasil penelitian dalam seluruh kajian ilmu keolahragaan, baik pendidikan, kepelatihan, dan lainya dalam pengembangan teori dan konsep yang belum pernah dipublikasikan. Jurnal ini memuat (1) kumpulan informasi baru, (2) hasil objektif dari suatu kajian ilmu keolahragaan, dan (3) rekomendasi.

2. Penulisan naskah menggunakan bahasa Indonesia secara benar. Panjang naskah antara 7-20 halaman, kertas ukuran quarto, diketik 1,5 spasi, tipe huruf Times New Roman, ukuran huruf 12, margin atas dan kiri 4 cm, kanan dan bawah $3 \mathrm{~cm}$.

3. Naskah ditulis dengan sistematika dan ketentuan sebagai berikut.

a. Judul: ditulis dengan singkat, padat, terdiri dari 5-15 kata, dan menggunakan bahasa Indonesia, harus mencerminkan substansi keilmuan yang diuraikan pada batang tubuh artikel. Judul utama (main title) dan anak judul (subtitle) dipisahkan dengan dua titik. Judul artikel dicetak 15 mm dibawah tepi atas, dengan huruf capital-kecil tebal. Judul subbab peringkat 1 dicetak capital semua, rata tepi kiri, tebal, peringkat 2 dicetak capital kecil, rata tepi kiri, tebal; peringkat 3 dicetak kapital-kecil, rata tepi kiri, miring-tebal.

b. Nama penulis: Nama penulis artikel ditulis tanpa disertai gelar akademik atau gelar apapun. Nama lengkap dengan gelar akademik boleh ditulis disebelah bawah halaman pertama artikel. Nama lembaga tempat bekerja penulis juga dibuat sebagai catatan kaki dihalaman pertama. Jika lebih dari tiga penulis, hanya penulis utama saja yang dicantumkan dibawah judul; nama penulis lain ditulis dalam catatan kaki.

c. Abstrak artikel kajian ilmiah/ konseptual adalah ringkasan dari isi artikel yang dituangkan secara padat menggunakan bahasa Indonesia dan bahasa inggris. Abstrak hasil penelitian memuat masalah atau tujuan, metode, dan hasil penelitian. Abstrak terdiri dari 100-300 kata yang disusun dalam satu 
paragraph dengan format esei bukan enumeratif, dan diketik dengan spasi tunggal serta dengan format yang lebih sempit dari teks utama.

d. Kata Kunci terdiri dari 3-5 kata, yaitu istilah-istilah yang mewakili ide atau konsep dasar yang dibahas dalam penulisan karya ilmiah. Kata kunci lazimnya berupa kata dasar atau kata yang berdiri sendiri (tunggal) bukan rangkaian kata.

e. Naskah hasil penulisan ditulis dengan urutan (1) judul, (2) nama penulis, (3) abstrak, (4) kata kunci, (5) bagian pendahuluan yang harus di akhiri dengan rumusan singkat (1-2 kalimat) tentang hal-hal pokok yang akan dibahas dan tujuan dari pembahasan. Untuk artikel hasil penelitian berisi (a) rumusan masalah, (b) tujuan, dan (c) deskripsi singkat mengenai kerangka pemikiran dalam pendahuluan, (6) isi memuat (a) metode penelitian, (b) hasil penelitian, dan (c) pembahasan. (8) simpulan dan saran, (9) daftar pustaka.

f. Naskah diluar hasil penelitian ditulis dengan urutan (1) judul, (2) nama penulis, (3) abstrak, (4) kata kunci, (5) pendahuluan yang memuat latar belakang dan rumusan masalah, (6) isi, (7) simpulan, dan (8) daftar pustaka.

g. Table dan gambar/ bagan di usahakan dicetak dalam satu halaman, nomor dan judul table dan gambar dicetak di atas table dengan huruf tebal. Isi dalam table dicetak dengan huruf normal (tidak tebal). Table hanya menggunakan garis horizontal (horizontal border)

h. Penulisan daftar pustaka

1) Buku ditulis dengan urutan: (a) nama akhir, (b) koma, (c) nama depan penulis, (d) titik, (e) tahun penerbitan, (f) titik, (g) judul buku dalam huruf miring, (h) titik, (i) edisi jika ada, (j) titik, (k) kota penerbitan, (l) titik dua, (m) nama penerbit, dan (n) titik.

2) Artikel ditulis dengan urutan: (a) nama akhir, (b) koma, (c) nama depan penulis, (d) titik, (e) tahun penerbitan, (f) titik, (g) tanda petik dua, (h) judul artikel, (i) titik, (j) tanda petik tutup, (k) nama jurnal dalam cetak miring, (l) volume, (m) nomor, dan (n) titik. Apabila artikel diterbitkan 
disuatu buku, tulis kata "dalam" sebelum nama editor buku tersebut, dan buku harus ditulis didalam daftar pustaka.

3) Skripsi, thesis, atau disertasi ditulis dengan urutan: (a) nama akhir, (b) koma, (c) nama depan penulis, (d) titik, (e) tahun, (f) titik, (g) judul dalam huruf miring, (h) skripsi/thesis/disertasi pada (nama perguruan tinggi yang bersangkutan), (i) nama kota, (j) titik dua, (k) tulisan "tidak diterbitkan", dan (1) titik. 